\title{
The Role of Social Responsibility Accounting Impact in Supporting Competitive Advantage for Industrial Establishment (Filed Study on the Company Matthew Petroleum)
}

\author{
Dr. Sherien Mamoun; Sayed Ahmed Mohamed \\ Assistant professor in accounting - Alfajr College for sciences and Technology
}

\begin{abstract}
The study examined the role of impact of social responsibility accounting in supporting the competitive advantage in industrial firms. The problem of study raised the following question: Did the disclosure of social responsibility cost help to support competitive advantage. The study aimed to Disclosing the cost of charitable donations helps to support the competitive advantage of industrial facilities. The study used the analytical descriptive method and for achieving the objectives of the study, the hypotheses below were tested as follows: the first hypothesis Disclosing the costs of social responsibility helps to support competitive advantage. The second hypothesis was The size of the expected return from the adoption of social responsibility helps to support the competitive advantage of industrial structures. The findings found that Disclosing the cost of disability training programs helps to support the competitive advantage of industrial facilities. The most important recommendations indicated that the industrial firms should increase their interest in serving the community in which working by providing jobs opportunities and share in supporting activities and social, cultural, healthy and sport services.
\end{abstract}

Keywords:- Social Responsibility Accounting, Competitive Advantage, Industrial Establishment.

\section{METHODOLOGICAL FRAMEWORK:}

Many private sector institutions have realized that they are not isolated from society and have been alerted to the need Expanding its activities to include more than productive activities. It is important to know the role of public shareholding companies in (Sustainable development) of societies and to bear the responsibility for economic development in a way that is reflected Directly at the social level. (Mohammed Salem, 2009: p.2.)

\section{* Statement of problem:}

For resolve this problem we formulated the following questions:

Q1: Did the disclosure of social responsibility cost help to support competitive advantage?
Q2: Did determining the expected return size from adopting the social responsibility help to support the competitive advantage for industrial structures?

* Importance of the study:

This study is of importance to the growing importance of this subject, which has been strongly re-emphasized in a world Business organization of different types and sizes, so that this theme supports the future direction of the organization Is considering further efforts to increase its social responsibilities, in order to achieve excellence in its performance.

* Objectives of the study:

The aim of this study is to achieve the following objectives:

a. Disclosing the cost of disability training programs helps to support the competitive advantage of industrial facilities .

b. Disclosing the cost of charitable donations helps to support the competitive advantage of industrial facilities.

* Hypotheses of the study:

To achieve the study's objectives, the following hypotheses were tested:

First hypotheses: Disclosing the costs of social responsibility helps to support competitive advantage.

Second hypotheses: The size of the expected return from the adoption of social responsibility helps to support the competitive advantage of industrial structures.

\section{* Sources of data collection:}

Initial Sources: The primary data of this study collected using questionnaire.

Secondary Sources: Secondary collected from references, previous studies related to research subject and internet.

* Methodology of the study:

The study adopted analytical descriptive approach .

* Limits of the study:

a. Spatial boundaries: Khartoum state .

b. Time limits: the year 2019 . 


\section{PREVIOUS STUDIES REVIEW}

The study of Carol Newman\& Neda (2020)Using a representative sample of more than 5,000 Vietnamese enterprises, we explore the firm-level productivity effects of corporate social responsibility (CSR). The data enables us to create 12 quantitative CSR measures, which can be grouped into two broader categories related to management and community-based CSR initiatives. We find a positive relationship between adoption of CSR initiatives and firm efficiency, and reveal that the impact is stronger for firms in non-competitive industries. Moreover, we show that local community focused CSR initiatives drive the aggregate effect. This suggests that socially responsible actions by firms are likely to pay-off when stakeholder engagement has a localized focus. We provide evidence of reciprocity by showing that employees accept a lower share of additionally generated value-added (controlling for productivity differences) in exchange for working in a company that signals 'good' corporate values.

The study of Youssef (2015) the problem of the study was the lack of interest of those responsible for business in Sudan Measurement and accounting disclosure of the social costs of their facilities and the positive return to meet The social responsibility of the business enterprises and therefore their performance in general, in addition to not They are aware of the importance of measuring the social costs and the bases used in this measurement and how to disclose them The importance of research in the definition of social responsibility for business enterprises and the importance of fulfilling them by enterprises, And the statement of accounting models for measuring social costs. The objective of the study is to study the bases of measurement Accounting disclosure of CSR costs for business enterprises, knowledge of the relationship between measurement Disclosure of social costs and raising the efficiency of financial performance in enterprises.

The study of Muhammad \& Faria ,(2012) corporate social responsibility (CSR) has been an important issue in business management since decades. The study proposes a research model from a strategic management perspective. On the foundation of social identity theory and resource-based perspective in developing this argument, the article theorizes CSR as a resource-generating activity by creating support networks, relationships and management of perceptions in the form of social and reputational capital. This article develops propositions for strategic use of CSR activities by creating social and reputational capita that ultimately leads to profitability. Theoretical and practical implications of the proposed model have been discussed.

\section{THEORETICAL FRAMEWORK OF SOCIAL RESPONSIBILITY:}

- Concept of social responsibility:

The concept of social responsibility went through a number of stages, up to the 1980s Where a new term began to appear among academics, is the term owner's groups Interest. the emergence of the theory of stakeholder groups has led to the development of contemporary societal responsibility theory the spread of this theory opened the eyes of individuals and public institutions to new sets of segments the community in which organizations must take care of their issues and needs. these are the main groups (customers, suppliers, shareholders, owners, employees, community) (Rami, 2009: p. $21)$. accordingly, it has the application of the theory of social responsibility is measured by the type of relationship between these groups and institutions, and the extent to which institutions respond to the needs of these groups and how to deal with them.ISO 26000 defines the social responsibility of enterprises: the actions carried out by the institution, to bear The responsibility of raising their activities to society and the environment where such actions are in line with the interests of society and sustainable development based on ethical behavior and compliance with the applicable law and the actors involved Among Governments. (Khalid, 2012: p. 108).

* Importance of accounting for social responsibility:

The importance of accounting for social responsibility can be illustrated by :(http://www.arabvolunteering.org)

1. Profit is no longer the sole criterion of preference by investors, but other necessary social, religious and political criteria are already affecting the investment decision.

2. It is necessary to evaluate the performance, in order to assess the overall performance of the unit must take into account the social dimension of the performance of the unit and its role in strengthening the relationship between the unit and its social environment.

3. Help to identify the contribution of the economic unit in the fields of environmental protection, consumers and human resources development.(shirazi,1991:p. 23 15)

4. The Secretariat of the presentation of the accounting data for the project requires the need to take the social processes of the project as an event that must be reported as an accounting.

5. The continued demand for the services of the accounting profession depends on the extent to which this profession meets the changing and renewable needs of society.

Social responsibility provides an improvement in the business environment prevailing in the business organization and leads to rumor Cooperation and interdependence between the various parties. (Taher al-Ghalibi, 2010: p. 52) 


\section{* Objective of accounting for social responsibility}

The objective of social accounting is," to internalize the social cost and benefits to determine a more relevant and exhaustive result that represents the socioeconomic profit of a firm. as a steward management responsibility should be evaluated in terms of both profit and the accomplishment social objectives( Fazal,p27 ,2013).

\section{* Elements of social responsibility:}

There are several ways to measure social responsibility, because of the difference in the definition of responsibility social and different dimensions of what is required to measure, and elements of social responsibility:

a. Contributions to social activities.

b. Staff accommodation policies.

c. Programs to preserve the environment and energy and programs for priority objectives.

d. the existence of a competent department of social responsibility, and means to employ people with disabilities. (Navarro,2014, p4).

\section{* Dimensions of Social Responsibility:}

Some researchers presented CSR elements within a general framework covering a range of Dimensional dimensions as these elements can be adapted in different scales considering the nature of the work of the organization And the influence of different stakeholder groups, according to Carroll, is social responsibility It comprises four key elements: Economic, Ethical and Legal, Philanthropy, and in this framework Kroll Carroll made a matrix among these The four elements and how they can affect each of the beneficiaries in the environment

a. Economic responsibility

b. Legal responsibility

c. Ethical responsibility

d. Charitable responsibility(Hanan,2003: p. 256)

\section{THEORETICAL FRAMEWORK OF COMPETITIVE ADVANTAGE :}

\section{* Concept of Competitive Advantage :}

Competition has become the language of the age and the place of interest of all individuals, institutions and nations alike is the factor Motivation and the engine that controls the steps of everyone and motivate them to work for more tenderness, creativity and creativity and achieve some degree of competitive advantage or excellence and excellence on their peers and competitors to achieve Highest levels of return or profitability.(Musa ,2014: p. 37).

\section{* Definitions of Competitive advantage:}

Competitive advantage has been defined as the means by which the company can win in its competition against others the competitive advantage of the company is the advantage of the company in the product market perspective that brings more from competitive position of the company means that competitive advantage means the company has a competitive position Advanced in the market . (Faisal Ghazi, 2012: p. 23).

- Importance of competitive advantage :

Having competitive advantage leads to superior profitability. The company's profitability is mainly based on three Factors: The value consumers attach to the company's products and the price charged by the company for its products and the costs of creating that value. There is an important difference between value and price. The value is something that is attributed or attributed to it The customer of the product, i.e. the pricing option chosen by the company, the price imposed by the company for the commodity or Service is usually less than the value that consumers attach to that product or service, and the basic rule Here (the more value the company creates, the more price options it will have). (Wael,2009 p. 34)

\section{* Objectives of Competitive advantage:}

The strategy is primarily aimed at gaining a competitive advantage not to ensure survival in the market but also to compete with competitors .

\section{* Competitive Advantage Features:} include:

The most important features of competitive advantage

a. To be sustainable and sustainable in the sense that the institution to achieve the long-term and not on Short term only.

b. Competitive advantages are relative to competitors or compared at different time periods Adjective makes understanding the features in an absolute framework difficult to investigate.

c. To be renewable according to the external environment data on the one hand and the internal resources and resources of the institution other.(Shames,2009,p22)

d. Be flexible in the sense that competitive advantages can be replaced by another easily facilitated or according to the considerations of changes in the external environment or the development of the resources and capabilities of the institution on the other hand.

e. The use of these competitive advantages should be commensurate with the objectives and outcomes that the organization wishes to achieve Both short and long term. (Ola Reform, 2008: p. 273)

* The advantages of competitive advantage are :

a. Low cost: Means that there is a commensurate cost to the product with the specifications in it .

b. Distance quality: Means the ability of the organization to provide products that correspond to the needs and desires of customers, and that quality means Different individuals look at the different outlook of the company versus different expectations of individuals.

c. Distance quality: By adding unique properties to the product you give them a competitive attractiveness that 
needs to be related The benefit to customers( Mahmoud Ali,2007, p. 143).

d. Distance flexibility :Flexibility is one of the most important competitive dimensions that an organization can distinguish from.

e. Distance customer response: the facility must be able to perform tasks better than competitors by determining and meet the needs of its customers and then will pay consumers greater value for their products.

f. Distance creativity: Representing creativity and innovation is one of the basic necessities of business management and organizations Time is on the rise and needs and ambitions( Hamid, 2012 P. 263).

\section{FIELD STUDY}

\section{* Field study procedures:}

The researchers discuss the method and procedures followed in the implementation of the study. This includes a description of the study community, the sample of the study, the method of preparing its tools, and the statistical methods used to test the hypothesis of the study. The study community is the total group of elements that the researcher seeks to generalize the results related to the problem. The study community consists of Matthew petroleum.

\section{* The study's sample:}

The sample of the study was determined according to its scientific specifications that achieve the objectives of the study from the internal auditor, external auditor, accountant, risk office, investment officer, and head of department, to achieve the purpose of the study.

\section{- Data collection:}

A total of (100) forms were distributed on the predefined and targeted sample to verify the hypotheses of the study. A total of (80) forms were collected for analysis, (80\%), To produce accurate results and disseminate them to the study community, the researchers are keen to vary the sample of the study in terms of its coverage on the following:

a. Individuals of different years of age (less than 30 years, 30 years and less than 35 years, 35 years and less than 40 years, more than 40 years).

b. Individuals with different qualifications (BSc, High Diploma, Master, PhD, Other).

c. Individuals from different scientific disciplines (accounting, financial and banking studies, business administration, accounting information systems, economics, other.).

d. Individuals of various functional occupations (internal auditor, external auditor, accountant, risk office, investment officer, department head, other). e. Individuals of different years of experience (less than 5 years, 5 years and less than 10 years, 10 years and less than 15 years, 15 years and less than 20 years, more than 20 years).

\section{* Tools of the study:}

The tools of the study are the means used by the researcher to collect the necessary data on the phenomenon studied. There are many tools used in the field of scientific research to obtain the necessary information and data. The researcher adopted the questionnaire as a main tool for collecting data from the study sample:

a. Applicable for information from a number of individuals.

b. Low cost and easy to apply.

c. Easy to develop questions and answer questions and answer questions. d. The questionnaire provides time for the respondent and gives him an opportunity to think.

e. Respondents in the questionnaire feel free to express opinions they fear others disagree with.

* Stability and truthfulness Study tools:

a. Stability and Virtual Honesty:

In order to ascertain the veracity of the questionnaires, the researchers presented the questionnaire to a number of academic arbitrators and specialists in the field of study. After the questionnaire was retrieved from the arbitrators, the proposed amendments were made. Stability and statistical honesty: The consistency of the test means that the scale gives the same results if used once under similar conditions. Stability means that if a test is applied to a group of individuals and their scores are monitored, then the same test is applied to the same group and the scores are obtained, the test is perfectly stable, also known as the accuracy and consistency of the measurements obtained from the test. The most commonly used methods for estimating the stability of a scale are (Half-way distribution using the Spearman-Brown formula, Alpha-Cronbach method, Method of re-application of the test).Honesty is a measure used to determine the degree of honesty among respondents through their answers to a given scale.

\section{b. Use a questionnaire for survey sample:}

The questionnaire was distributed to a sample of (5) individuals from the research community and from outside the research sample in accordance with their characteristics with the sample of the study to calculate the stability factor, to determine the degree of response of the respondents to the questionnaire and to identify ambiguous questions and to provide preliminary testing of hypotheses and to clarify some design and methodological problems. The stability test for the questionnaire was conducted using the alpha-Cronbach coefficient and the result was 0.873 . This means that the data is stable as shown in Table (1) below: 


\begin{tabular}{|c|c|c|c|}
\hline Number & Axis & Number of ferries & Stability(constancy) \\
\hline 1 & first hypothesis & 5 & 0.939 \\
\hline 2 & second hypothesis & 5 & 0.953 \\
\hline & Total & 10 & 0.972 \\
\hline
\end{tabular}

Table (1):- Alpha Cronbach Coefficient of the Questionnaire

Source: Researcher, 2020.

The above table shows that the Kronbach coefficient for all the terms of the questionnaire is 0.972 which is high and the reference to the terms of the questionnaire is that the increase in the value of the Cronbach coefficient means increasing the credibility of the data. This means that the measure measures what is measured.

\section{Used Statistical methods:}

To achieve the objectives of the study and to verify its hypotheses, the statistical methods used are (Frequency distribution of responses, Percentages, Spearman-Brown equation to calculate the coefficient of stability, Arithmetic mean, standard deviation and variance and chi - square test to denote hypotheses).
* Data analysis and hypothesis testing

The researchers analyzed personal data, questionnaire data and tested the hypotheses of the study using statistical methods. In addition, a comparison is made between the most important results of the field study and the results of the previous studies, as follows:

\section{Analysis of the questionnaire data:}

First hypothesis: Disclosing the costs of social responsibility helps to support competitive advantage.

\begin{tabular}{|c|c|c|c|c|c|c|c|c|c|c|c|}
\hline \multirow[t]{3}{*}{ No } & \multirow[t]{3}{*}{ Sentences } & \multicolumn{10}{|c|}{ Frequency and percentage $\%$} \\
\hline & & \multicolumn{2}{|c|}{$\begin{array}{l}\text { Strongly } \\
\text { Disagree }\end{array}$} & \multicolumn{2}{|c|}{ disagree } & \multicolumn{2}{|c|}{ Neutral } & \multicolumn{2}{|c|}{ Agree } & \multicolumn{2}{|c|}{ Strongly agree } \\
\hline & & $\mathrm{F}$ & $\mathrm{P}$ & $\mathrm{f}$ & $p$ & $\mathrm{f}$ & $P$ & $\bar{F}$ & $P$ & $\mathrm{~F}$ & $P$ \\
\hline 1 & $\begin{array}{l}\text { Disclosing the cost of product modifications to } \\
\text { increase the degree of reliability helps to } \\
\text { support the competitive advantage of industrial } \\
\text { facilities }\end{array}$ & 1 & $3.3 \%$ & 0 & $0 \%$ & 0 & $0 \%$ & 1 & $3.3 \%$ & 28 & $93.3 \%$ \\
\hline 2 & $\begin{array}{c}\text { Disclosure of social donations helps to support } \\
\text { the competitive advantage of industrial } \\
\text { facilities }\end{array}$ & 1 & $3.3 \%$ & 0 & $0 \%$ & 0 & $0 \%$ & 4 & $\begin{array}{c}13.3 \\
\%\end{array}$ & 25 & $83.3 \%$ \\
\hline 3 & $\begin{array}{l}\text { Disclosure of the additional cost of pollution } \\
\text { control devices helps to support the competitive } \\
\text { advantage of industrial facilities }\end{array}$ & 1 & $3.3 \%$ & 0 & $0 \%$ & 0 & $0 \%$ & 1 & $3.3 \%$ & 28 & $93.3 \%$ \\
\hline 4 & $\begin{array}{l}\text { Disclosing the cost of disability training } \\
\text { programs helps to support the competitive } \\
\text { advantage of industrial facilities }\end{array}$ & 1 & $3.3 \%$ & 0 & $0 \%$ & 0 & $0 \%$ & 0 & $0 \%$ & 29 & $96.7 \%$ \\
\hline 5 & $\begin{array}{l}\text { Disclosing the cost of charitable donations } \\
\text { helps to support the competitive advantage of } \\
\text { industrial facilities }\end{array}$ & 1 & $3.3 \%$ & 0 & $0 \%$ & 0 & $0 \%$ & 1 & $3.3 \%$ & 28 & $93.3 \%$ \\
\hline
\end{tabular}

Table (2):- The frequency distribution of the responses of the sample members of the study for the first hypothesis phrases Source: Prepared by researcher, based on field study's data, 2020

From table (2) that explains the ratios and frequencies of the hypothesis expressions, which states, "disclosing the costs of social responsibility helps to support competitive advantage.

.", the researcher noticed that, the respondents, answers are strongly agree and agree. 
ISSN No:-2456-2165

\begin{tabular}{|c|c|c|c|c|}
\hline No & Sentences & Mean & Mode & Explanation \\
\hline 1 & $\begin{array}{c}\text { Disclosing the cost of product modifications to increase } \\
\text { the degree of reliability helps to support the competitive } \\
\text { advantage of industrial facilities }\end{array}$ & 4.76 & 5 & Strongly agree \\
\hline 2 & $\begin{array}{c}\text { Disclosure of social donations helps to support the } \\
\text { competitive advantage of industrial facilities }\end{array}$ & 4.73 & 5 & Strongly agree \\
\hline 3 & $\begin{array}{c}\text { Disclosure of the additional cost of pollution control } \\
\text { devices helps to support the competitive advantage of } \\
\text { industrial facilities }\end{array}$ & 4.80 & 5 & Strongly agree \\
\hline 4 & $\begin{array}{c}\text { Disclosing the cost of disability training programs helps } \\
\text { to support the competitive advantage of industrial } \\
\text { facilities }\end{array}$ & 4.86 & 5 & Strongly agree \\
\hline 5 & $\begin{array}{c}\text { Disclosing the cost of charitable donations helps to } \\
\text { support the competitive advantage of industrial facilities }\end{array}$ & 4.83 & 5 & \\
\hline
\end{tabular}

Table (3):- The mean and the mode of the responses of the sample members of the study for the phrases of the first hypothesis Source: Prepared by researcher, based on field study's data, 2020

From table (3), the researcher noticing that the descriptive statistics of the first hypothesis's terms which states, "Disclosing the costs of social responsibility helps to support competitive advantage., the arithmetic mean is in the range between (4.73 - 4.86) and the mode is in the range between (4-5). According to the Five-digit Liker's scale, the respondents, answers are; strongly agree and agree.

\begin{tabular}{|c|c|c|c|c|}
\hline No & Sentences & Chi-square & $\begin{array}{c}\text { Degree of } \\
\text { freedom }\end{array}$ & $\begin{array}{c}\text { Statistical } \\
\text { significance }\end{array}$ \\
\hline 1 & $\begin{array}{c}\text { Disclosing the cost of product modifications to increase } \\
\text { the degree of reliability helps to support the } \\
\text { competitive advantage of industrial facilities }\end{array}$ & 64.310 & 1 & .000 \\
\hline 2 & $\begin{array}{c}\text { Disclosure of social donations helps to support the } \\
\text { competitive advantage of industrial facilities }\end{array}$ & 52.186 & 2 & .000 \\
\hline 3 & $\begin{array}{c}\text { Disclosure of the additional cost of pollution control } \\
\text { devices helps to support the competitive advantage of } \\
\text { industrial facilities }\end{array}$ & 51.866 & 2 & .000 \\
\hline 4 & $\begin{array}{c}\text { Disclosing the cost of disability training programs helps } \\
\text { to support the competitive advantage of industrial } \\
\text { facilities }\end{array}$ & 41.351 & 2 & .000 \\
\hline 5 & $\begin{array}{c}\text { Disclosing the cost of charitable donations helps to } \\
\text { support the competitive advantage of industrial } \\
\text { facilities }\end{array}$ & 53.264 & & .000 \\
\hline
\end{tabular}

Table (4):- Test of Chi - square for the first hypothesis

Source: Prepared by researcher, based on field study's data, 2020.

In order to test the validity of the hypothesis, which states, "Disclosing the costs of social responsibility helps to support competitive advantage. The chi-square test used for the axis expressions. The values of the chi-square calculated as $(64.310,52.186$, $51.866,41.351,53.264)$, with degrees of freedom (1-2). And with the statistical significance for all terms (0.00), When comparing the level of statistical significance with the permissible level of significance (0.05), we find that the level of statistical significance is less than the level of morale, which means of terms hypothesis. From above discussion, the researcher conclude that, the first hypothesis that states, "Disclosing the costs of social responsibility helps to support competitive advantage.

The second hypothesis: "The size of the expected return from the adoption of social responsibility helps to support the competitive advantage of industrial structures. 


\begin{tabular}{|c|c|c|c|c|c|c|c|c|c|c|c|}
\hline \multirow[t]{3}{*}{ No } & \multirow[t]{3}{*}{ Sentences } & \multicolumn{10}{|c|}{ Frequency and percentage $\%$} \\
\hline & & \multicolumn{2}{|c|}{$\begin{array}{l}\text { Strongly } \\
\text { Disagree }\end{array}$} & \multicolumn{2}{|c|}{ disagree } & \multicolumn{2}{|c|}{ Neutral } & \multicolumn{2}{|c|}{ Agree } & \multicolumn{2}{|c|}{$\begin{array}{l}\text { Strongly } \\
\text { agree }\end{array}$} \\
\hline & & $\mathrm{F}$ & $\mathrm{P} \%$ & $\mathrm{f}$ & $\mathrm{p}$ & $\mathrm{F}$ & $\mathrm{P}$ & $\mathrm{F}$ & $\mathrm{P}$ & $\mathrm{F}$ & $\mathrm{P}$ \\
\hline 1 & $\begin{array}{l}\text { Access to tax benefits as a result of social } \\
\text { responsibility competitive advantage of industrial } \\
\text { facilities }\end{array}$ & 1 & $\begin{array}{c}3.3 \\
\%\end{array}$ & 0 & $0 \%$ & 1 & $\begin{array}{c}3.3 \\
\%\end{array}$ & 1 & $3.3 \%$ & 27 & $90 \%$ \\
\hline 2 & $\begin{array}{c}\text { Obtaining customs exemptions when collecting } \\
\text { environmental improvement equipment helps to } \\
\text { support the competitive advantage of industrial } \\
\text { facilities }\end{array}$ & 1 & $\begin{array}{c}3.3 \\
\%\end{array}$ & 0 & $0 \%$ & 1 & $\begin{array}{c}3.3 \\
\%\end{array}$ & 7 & $\begin{array}{c}23.3 \\
\%\end{array}$ & 21 & $70 \%$ \\
\hline 3 & $\begin{array}{l}\text { The increase in the volume of sales as a result of } \\
\text { the demand for the products of the establishment } \\
\text { competitive to support the competitive advantage } \\
\text { of industrial facilities }\end{array}$ & 1 & $\begin{array}{c}3.3 \\
\%\end{array}$ & 0 & $0 \%$ & 1 & $\begin{array}{c}3.3 \\
\%\end{array}$ & 2 & $6.7 \%$ & 26 & $\begin{array}{c}86.7 \\
\%\end{array}$ \\
\hline 4 & $\begin{array}{l}\text { Increasing the value of shares in the money market } \\
\text { contributes to the competitive advantage of } \\
\text { industrial structures }\end{array}$ & 1 & $\begin{array}{c}3.3 \\
\%\end{array}$ & 0 & $0 \%$ & 1 & $\begin{array}{c}3.3 \\
\%\end{array}$ & 3 & $10 \%$ & 25 & $\begin{array}{c}83.3 \\
\%\end{array}$ \\
\hline 5 & $\begin{array}{l}\text { Increasing access to finance contributes to the } \\
\text { competitive advantage of industrial structures }\end{array}$ & 1 & $\begin{array}{c}3.3 \\
\%\end{array}$ & 0 & $0 \%$ & 1 & $\begin{array}{c}3.3 \\
\%\end{array}$ & 1 & $3.3 \%$ & 27 & $90 \%$ \\
\hline
\end{tabular}

Table (5):- The frequency distribution of the responses of the sample members of the study for the second hypothesis phrases Source: Prepared by researcher, based on field study's data, 2020.

From table (5), which explains the ratios and frequencies of the hypothesis terms, which states, "The size of the expected return from the adoption of social responsibility helps to support the competitive advantage of industrial structures. "the researcher noticed that, the respondents, answers are strongly agree and agree.

\begin{tabular}{|c|c|c|c|c|}
\hline No & Sentences & Mean & mode & Explanation \\
\hline 1 & $\begin{array}{c}\text { Access to tax benefits as a result of social responsibility } \\
\text { competitive advantage of industrial facilities }\end{array}$ & 4.76 & 5 & Strongly agree \\
\hline 2 & $\begin{array}{c}\text { Obtaining customs exemptions when collecting environmental } \\
\text { improvement equipment helps to support the competitive } \\
\text { advantage of industrial facilities }\end{array}$ & 4.56 & 5 & Strongly Agree \\
\hline 3 & $\begin{array}{c}\text { The increase in the volume of sales as a result of the demand for } \\
\text { the products of the establishment competitive to support the } \\
\text { competitive advantage of industrial facilities }\end{array}$ & 4.73 & 5 & Strongly agree \\
\hline 5 & $\begin{array}{c}\text { Increasing the value of shares in the money market contributes to } \\
\text { the competitive advantage of industrial structures }\end{array}$ & 4.70 & 5 & Strongly agree \\
\hline 5 & $\begin{array}{c}\text { Increasing access to finance contributes to the competitive } \\
\text { advantage of industrial structures }\end{array}$ & 4.77 & 5 & \\
\hline
\end{tabular}

Table (6):- The mean and the mode of the responses of the sample members of the study for the phrases of second hypothesis Source: Prepared by researcher, based on field study's data, 2020

From table (6), the researcher noticed from the descriptive statistics of the first hypothesis's terms, which states, "The size of the expected return from the adoption of social responsibility helps to support the competitive advantage of industrial structures.", the Arithmetic mean is in the range (4.56 - 4.77), and the mode is in the range between (2-5). According to the five-digit Likert's scale, the respondents' answers are; strongly agree and agree. 


\begin{tabular}{|c|c|c|c|c|}
\hline No & Sentences & Chi-square & $\begin{array}{c}\text { Degree of } \\
\text { freedom }\end{array}$ & Statistical significance \\
\hline 1 & $\begin{array}{c}\text { Access to tax benefits as a result of social responsibility } \\
\text { competitive advantage of industrial facilities }\end{array}$ & 51.786 & 1 & .000 \\
\hline 2 & $\begin{array}{c}\text { Obtaining customs exemptions when collecting } \\
\text { environmental improvement equipment helps to support } \\
\text { the competitive advantage of industrial facilities }\end{array}$ & 32.374 & 2 & .000 \\
\hline 3 & $\begin{array}{c}\text { The increase in the volume of sales as a result of the } \\
\text { demand for the products of the establishment } \\
\text { competitive to support the competitive advantage of } \\
\text { industrial facilities }\end{array}$ & 31.635 & 2 & .000 \\
\hline 4 & $\begin{array}{c}\text { Increasing the value of shares in the money market } \\
\text { contributes to the competitive advantage of industrial } \\
\text { structures }\end{array}$ & 63.828 & 2 & .000 \\
\hline 5 & $\begin{array}{c}\text { Increasing access to finance contributes to the } \\
\text { competitive advantage of industrial structures }\end{array}$ & 63.159 & 2 & .000 \\
\hline
\end{tabular}

Table (7)Test of Chi - square for the second hypothesis

Source: Prepared by researcher, based on field study's data, 2020.

In order to test the validity of the hypothesis, which states, "The size of the expected return from the adoption of social responsibility helps to support the competitive advantage of industrial structures", the Chi-square test used for the axis expressions. The values of the Chi-square calculated as $(51.786,32.374,31.635,63.828,63.159)$, with degrees of freedom (1-2), and with the statistical significance for all terms (0.00). When comparing the level of statistical significance with the permissible level of significance $(0.05)$ we find that the level of statistical significance is less than the level of morale, which means of terms hypothesis. From above discussion, the researcher conclude that, the second hypothesis that states, "The size of the expected return from the adoption of social responsibility helps to support the competitive advantage of industrial structures" achieved.

\section{CONCLUSIONS AND RECOMMENDATIONS}

\section{* First : Conclusions}

After completing the theoretical framework of the study and data, researcher found the following results:

a. Obtaining customs exemptions when collecting environmental improvement equipment helps to support the competitive advantage of industrial facilities.

b. The increase in the volume of sales as a result of the demand for the products of the establishment contribute to support the competitive advantage of industrial facilities.

c. Increasing the value of shares in the money market contributes to the competitive advantage of industrial structures.

d. Increasing access to finance contributes to the competitive advantage of industrial structures. e. Disclosure of the additional cost of pollution control devices helps to support the competitive advantage of industrial facilities.

f. Disclosing the cost of disability training programs helps to support the competitive advantage of industrial facilities.

* Second: Recommendations :

Base on the results of this study, researcher recommended the following:

a. Emphasize the adoption of social responsibility by the Sudanese companies and that responsibility Social impacts have clear implications for the organization's performance and sustainability. This is confirmed by this study Previous studies have examined the relationship between social responsibility and competitive advantage.

b. Emphasize the need to pay attention to the humanitarian aspect of social responsibility because of its role in Dissemination of the Organization's profile, thereby creating a sustainable competitive advantage.

c. Increase the interest of the company to serve the community in which it operates through the provision of employment opportunities and contribute to supporting social, cultural, health and sports activities and services.

d. The necessity of cooperation of all companies operating in the oil sector, the development of a clear national strategy Contribute to enhancing their social responsibilities towards the environment and society in which they operate Through cooperation and coordination.

e. Increase coordination between responsibility centers and work to clarify relations between them.

f. Work to maintain the incentive system in the company to increase interest in human cadres, because it is the main component in the success of companies. 


\section{REFERENCES}

[1]. Carol Newman, John Rand, Finn Tarp \& Nelda ,Corporate Social Responsibility in a Competitive Business Environment, Journal of Development Studies, January 2020.

[2]. Youssef Harmon Mohamed study (2015) The role of accounting measurement and disclosure on social costs in raising the efficiency of financial performance in the business premises Case study of Sudan Telecom Company (Khartoum: Sudan University of Science and Technology .

[3]. Muhammad Mohtsham Seed \& Faria Arshad, Corporate social responsibility as a source of competitive advantage: The mediating role of social capital and reputational capital ,Journal of Database Marketing \& Customer Strategy Management volume 19, pages219232(2012) .

[4]. Khalid Al-Qattani, The role of strategic management accounting in strengthening competitiveness in public companies for metal industries, College of Management and Economics, University of Mosul, Volume 34, No. 2012, 108, p. 203.

[5]. Shames, Rami, Customer Satisfaction and Role in Achieving Competitive Advantage, Applied Study in Air Transport Services, Unpublished Master Thesis, University of Damascus, Syria, 2009, p21.

[6]. Ahmed Al-Sharif, to develop the concepts of social responsibility and competitive advantages for companies, Saudi Social Responsibility Network. 11Economic Journal: 2013.

[7]. Chen, C.; Zhou, Z.L. Research on the Influence of Corporate Social Responsibility on the Persistence of Corporate Competitive Advantage. Forum Sci. Technol. China 2014, 5, 68-73.

[8]. Jamali, D.; Karam, C. Corporate social responsibility in developing countries as an emerging field of study. Int. J. Manag. Rev. 2018, 20, 32-61.

[9]. Du, M.Q. Integration of resources, capabilities, external environment, strategy and competitive advantage. Manag. World 2003, 10, 145-146.

[10]. Dahlsrud, A. How corporate social responsibility is defined: An analysis of 37 definitions. Corp. Soc. Responsib. Environ. Manag. 2008, 15, 1-13. 